\title{
Design of Solar System by Implementing ALO Optimized PID Based MPPT Controller
}

\author{
Raj Kumar Sahu* and Binod Shaw \\ Department of Electrical Engineering, NIT, Raipur, C.G, India.
}

Received January 5, 2018; Accepted March 15, 2018; Published April 26, 2018

\begin{abstract}
This paper is a strive approach to design offgrid solar system in association with DC-DC boost converter and MPPT. The tuned PID based MPPT technique is adopted to extract maximum power from the solar system under certain circumstances (temperature and irradiance). The design parameters of PID controller play an imperative aspect to enhance the performance of the system. Ant lion Optimizer (ALO) algorithm is adopted to optimize PID parameters to contribute relevant duty cycle for DC-DC boost converter to maximize output power and voltage. $\mathrm{P}$ and $\mathrm{O}$ based MPPT technique is implemented to validate the supremacy of PID based MPPT to enhance the response of the system. In this paper, the proposed ALO optimized PID controller based MPPT technique is performed better over conventional $P \& O$ technique by conceding the oscillation, time response, settling time and maximum values of voltage, current and power of the solar system.
\end{abstract}

Keywords: Photovoltaic system (PV); Maximum Power Point Tracking (MPPT); Perturb and Observe (P $\& O)$; Proportional-Integral-Derivative (PID) controller; Ant lion Optimizer (ALO) algorithm

\section{INTRODUCTION}

In the present scenario, renewable energy source plays a significant approach to meet the fast-growing load demand. Solar is an imperative concern among renewable energy due to its noise free, eco-friendly, and easy maintenance with impressive life span. Solar power is nonlinear and tough to guess. Solar energy falling on solar photovoltaic (PV) system can precisely disciple into electrical energy. Irradiation and temperature enormously influence the voltage and current which make them nonlinear. PV systems need to minimize cost, reduce the size and increase the efficiency. The maximum power point (MPP) is the extraction of power from solar cell under specific circumstances. Load current primarily relies upon radiation, ambient temperature, and cell temperature. Maximum Power Point Tracking (MPPT) is the process to track the maximum power by optimizing the load resistance properly in any environmental condition.

\section{LITERATURE SURVEY}

Many researchers have implemented various techniques to enhance the efficiency of the solar cell by enhancing the MPPT techniques during last few decades. Esram and Chapman [1] have contributed 19 different MPPT techniques and provided a fair 
interpretation for researchers to adopt relevant techniques. The $\mathrm{P} \& \mathrm{O}$ of variable step size is proposed by Al-Diab and Sourkounis [2], and the step size is tuned automatically and compared with the conventional method. Ishaque and Salam [3] have contributed a brief literature to the MPPT design by adopting soft computing methods during partial shading. The variable CS MPPT algorithm is validated by comparing with conventional $\mathrm{P}$ $\&$ O and PSO MPPT algorithm in three distinct case studies and is described in [4]. The efficiency of the partial shading PV module is enhanced up to $32 \%$ by using the current of non-shaded module in [5]. The fuzzy logic controller based MPPT algorithm with 8-bit microcontroller is compared with conventional P \& O MPPT algorithm in [6]. Neural network based MPPT is implemented in 230-watt PV system in [7]. A brief literature survey on MPPT design is described beautifully in [8] and [9]. The $\mathrm{P} \& \mathrm{O}$ algorithm is optimized to enhance the efficiency of the MPPT technique in [10]. Adaptive Fuzzy-PI controller is implemented as MPPT and the role of climate change on PV module is well established in [10] and [11], respectively. Application of improved optimization techniques such as Adaptive Symbiotic Organism Search (ASOS) and Modified Group Hunting Search (MGHS) are validated in power system to tune controller parameters [12, 13]. Various soft computing techniques and optimization techniques are adopted to enhance the performance of MPPT of PV module in [14-19].

In this paper, Ant lion Optimizer (ALO) algorithm [20] optimized PID controller based MPPT technique is strived to validate over $\mathrm{P} \& \mathrm{O}$ technique to enhance the power and voltage of the system by contributing gate pulse of DC-DC boost converter. The proposed experiment is executed in MATLAB/SIMULINK environment.

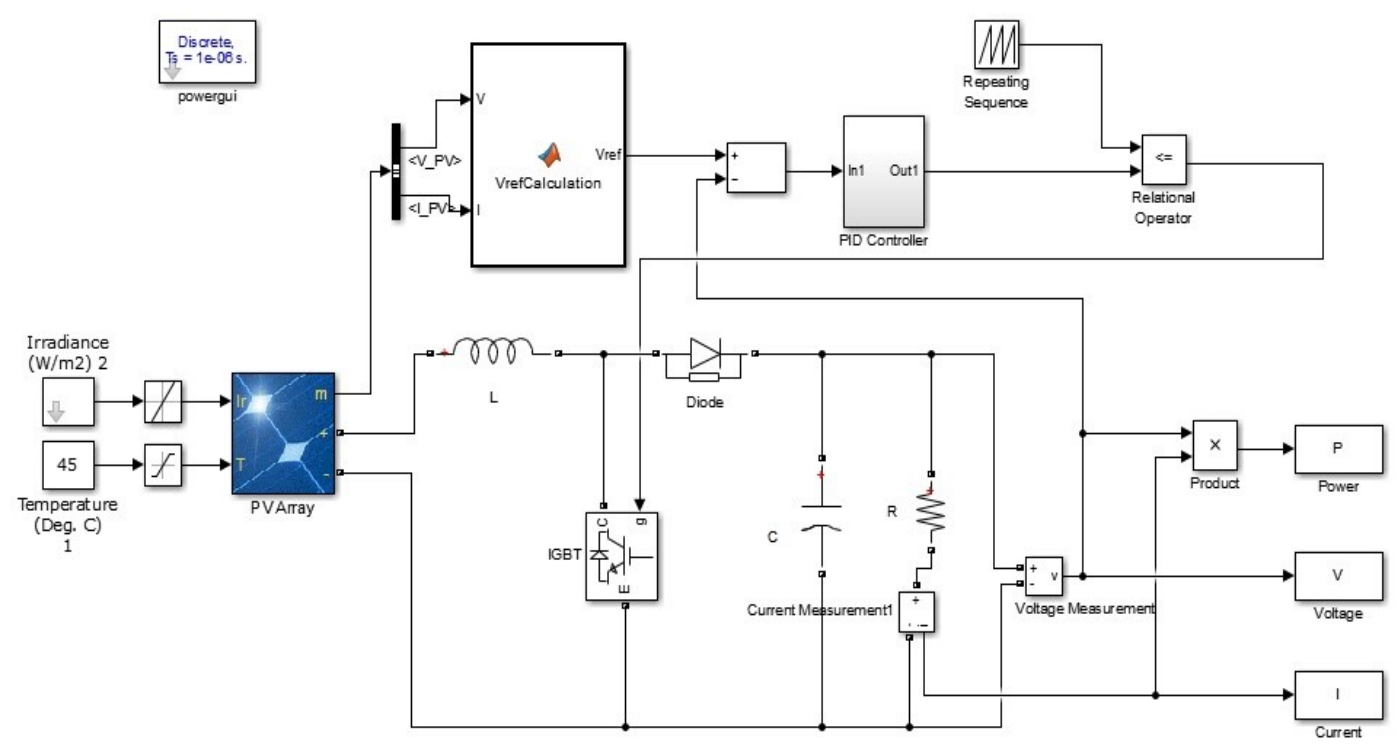

Figure 1. Simulink model of PID based solar system 


\section{SYSTEM INVESTIGATED}

The Simulink model of PV module with PID based MPPT controller is portrayed in Figure 1. The proposed isolated solar system is portrayed in Figure 2, basically consisting of PV array, DC-DC Boost converter and MPPT controller. MPPT controller regulates gate pulse of boost converter by conceding the voltage and current of the PV module. The regulated pulse of the converter enhances the efficiency of the solar system.

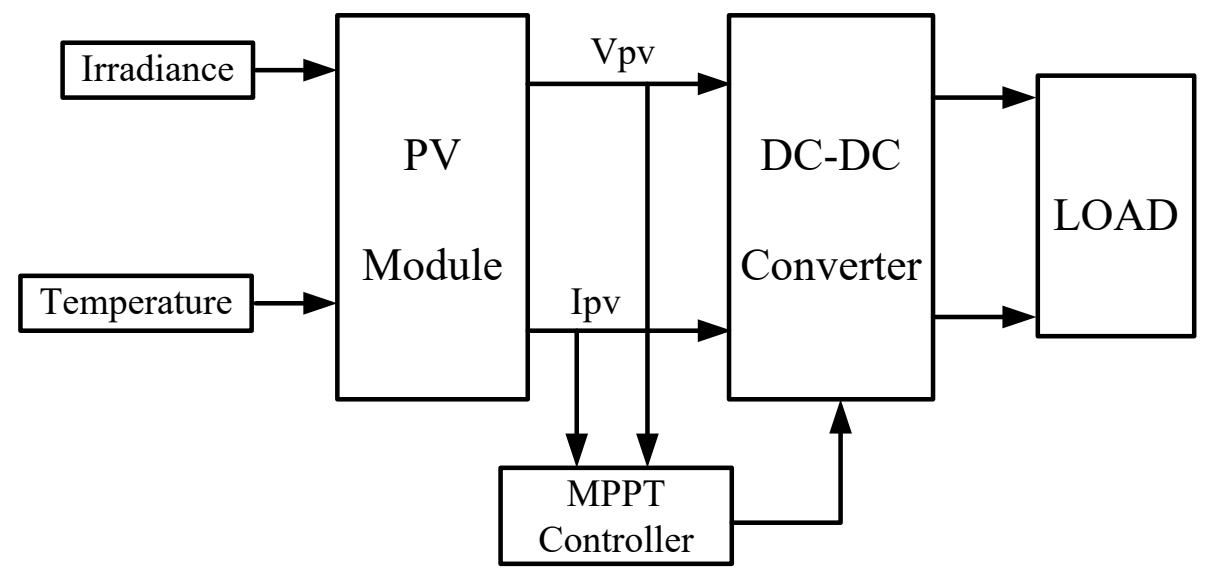

Figure 2. Block diagram of solar system

\section{PV Module}

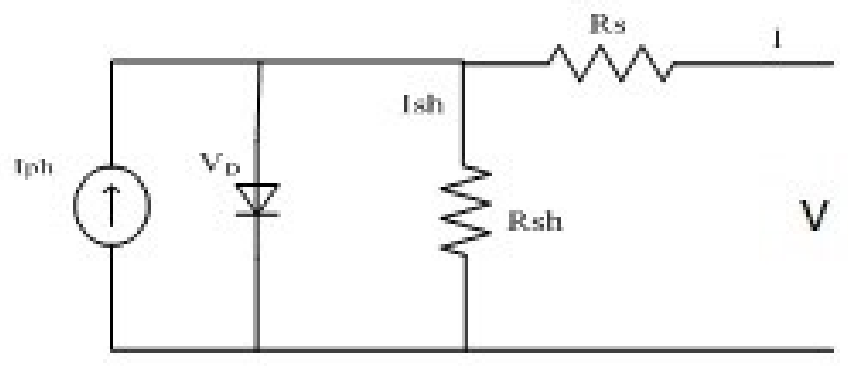

Figure 3. Equivalent circuit of solar cell

PV cells are associated in series and parallel to enhance the voltage and current. The equivalent circuit is portrayed in Figure 3.

The equivalent solar system may be explained through equations (1)-(4).

$$
\begin{aligned}
& I_{r r}=I_{s c r} e^{\left(q V_{o c} / K N_{s} A T_{r k}\right)-1} \\
& I_{d}=I_{r r}\left(T_{a k} / T_{r k}\right)^{3} e^{\left[\left(E_{g} K / K A\right)\left(1 / T_{r k}-1 / T_{a k}\right)\right]} \\
& I_{P H}=I_{s c r}+\left(K_{i}\left(T_{a k}-T_{r k}\right)\right) S / 1000 \\
& I_{o}=N_{p} I_{P H}-N_{p} I_{d}\left\{e^{\left.\left(q / N_{s} A K T_{a k}\right)\left(V_{o}+I_{o} R_{s}\right)\right]}-1\right\}
\end{aligned}
$$

Where Io $=$ PV module current

$\mathrm{Vo}=\mathrm{PV}$ module voltage

Trk $=$ Reference temperature in Kelvin

Tak $=$ Operating temperature in Kelvin 


$$
\begin{aligned}
& \mathrm{S}=\text { Irradiance } \mathrm{W} / \mathrm{m}^{2} \\
& \mathrm{q}=\text { Charge of electron, } 1.6 \times 10-19 \mathrm{C} \\
& \mathrm{A}=\text { Ideality factor, } 1.3 \\
& \mathrm{~K}=\text { Boltzman constant } \\
& \mathrm{Eg}=\text { Band Gap } \\
& \mathrm{Iscr}=\mathrm{S} . \mathrm{C} \text { current } \\
& \mathrm{Ns}=\text { Cells connected in series } \\
& \mathrm{Np}=\text { Cells connected in parallel } \\
& \mathrm{Ki}=\text { S.C temperature co-efficient } \\
& \mathrm{Rs}=\text { Series Resistance } \\
& \mathrm{IPh}=\text { Light generated current } \\
& \mathrm{Irr}=\text { Reverse Saturation current }
\end{aligned}
$$

\section{DC-DC boost converter}

The basic purpose of design of boost converter is to boost the output voltage of the dc system. The output of the converter is enormously influenced by the switching frequency (gate pulse). Figure 4 represents the boost converter and the output of the converter may be characterized in equation (5)

$$
V_{\text {out }}=\frac{1}{1-D} V_{\text {in }}
$$

$\mathrm{D}$ is the duty cycle of the converter and is characterized in equation (6).

$$
D=\frac{t_{\text {on }}}{t_{\text {on }}+t_{\text {off }}}
$$

On time and off time of the switch are expressed in equations (7) and (8), respectively, by conceding switching period $\left(\mathrm{T}_{\mathrm{s}}\right)$.

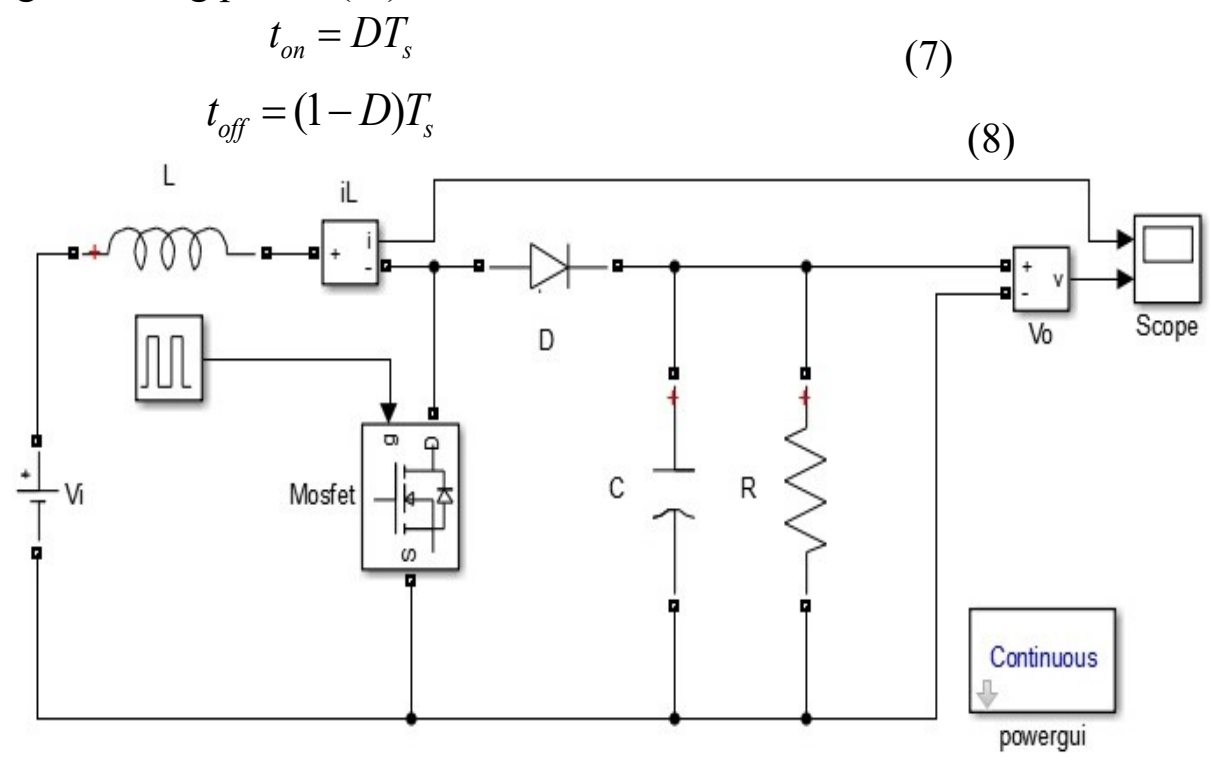

Figure 4. Boost converter 
The parameters of boost converter are tabulated in Table 1.

Table 1. Boost converter parameters

\begin{tabular}{|l|l|}
\hline Model Components & Parameters \\
\hline Inductance, $\mathrm{L}$ & $1 \mu \mathrm{H}$ \\
\hline Capacitance, C & $3000 \mu \mathrm{F}$ \\
\hline Load, R & $24 \Omega$ \\
\hline DC voltage, Vdc & $12 \mathrm{~V}$ \\
\hline Switching frequency & $10000 \mathrm{~Hz}$ \\
\hline
\end{tabular}

\section{PID based MPPT controller}

The primary purpose of MPPT technique is to track the maximum power from the PV module by concerning the array voltage and power. In this paper, reference voltage (Vref) is developed by correlating the instant power $(\mathrm{Pk})$ and previous power $(\mathrm{Pk}-1)$ as portrayed in Figure 5.

The error signal achieved by comparing reference voltage with output voltage of boost converter is fed to the PID controller. The output of PID controller is used as gate pulse of the switch to enhance the power of the solar cell. The structure of PID controller is illustrated in Figure 6 and can be expressed as in equation (9).

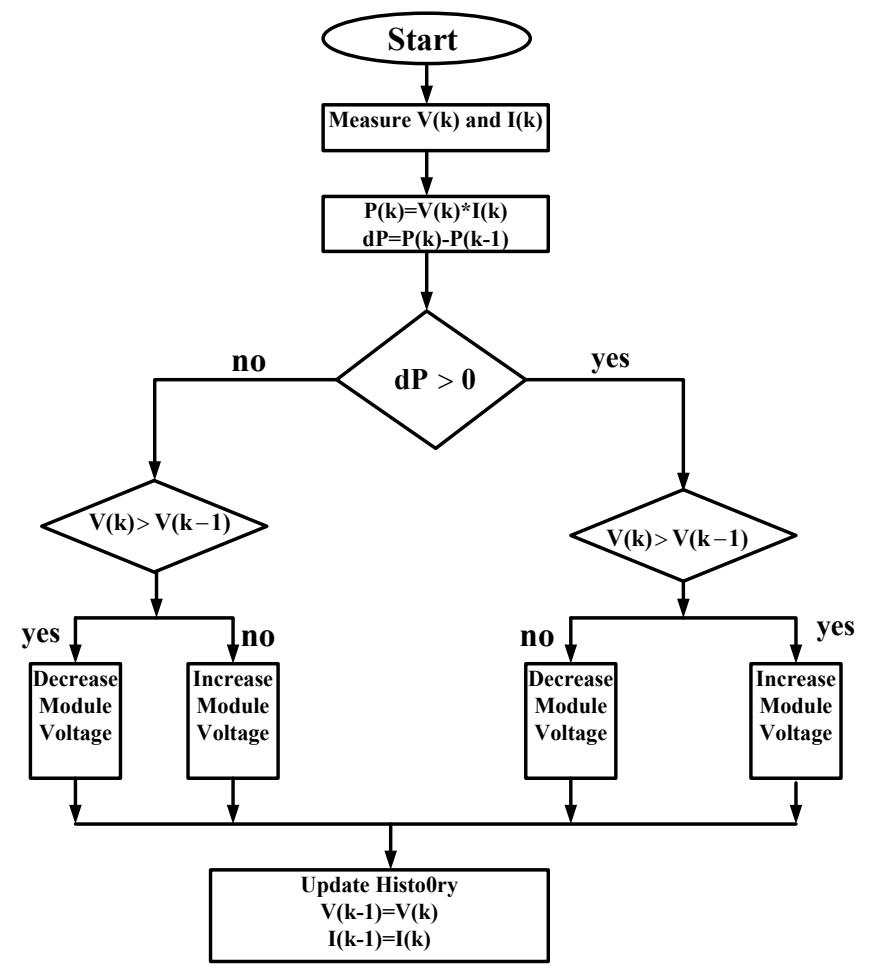

Figure 5. Vref calculation algorithm 


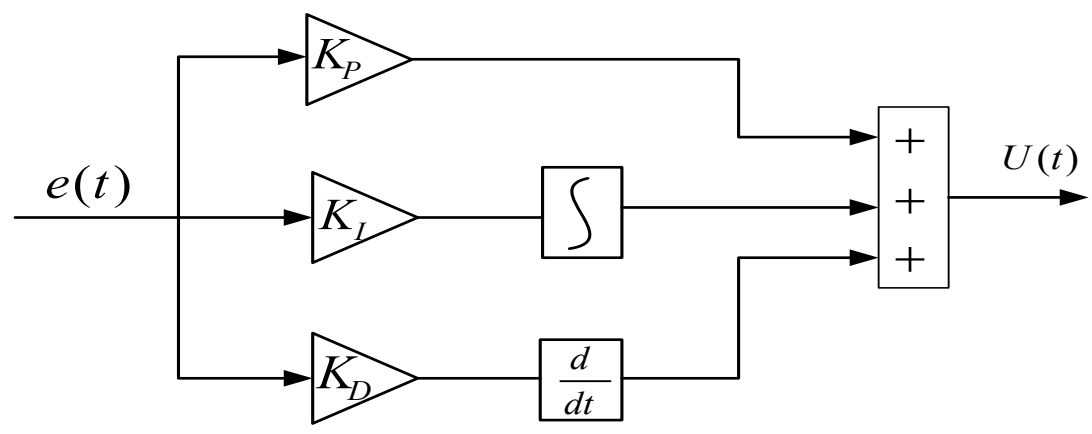

Figure 6. PID controller structure

$$
u(t)=K_{p} . e(t)+K_{i} \int_{0}^{t} e(t) \cdot d t+K_{d} \frac{d}{d t} e(t)
$$

\section{ANT LION OPTIMIZER ALGORITHM}

The affiliation among predator (ant lion) and prey (ant) is intelligently portrayed as optimization technique by S. Mirjalili [21]. ALO algorithm is derivational from the planning of hawking of ant as food by ant lion to sustain and become capable. Ant lion creates reversed pyramid trap for the randomly moving ants to be captured into. Ant lion downtime in the ground of the soil constructs hole to trap ant or other bugs. Ants move randomly for searching food and sleep into the hole due to the pointed edge and loose sand of the hole. Here and there preys try to protect out from the opening however ant lion impels sands to the edge of the gap to make the prey slip into its jaw. The extent of opening is specifically relying on the starvation of antlion. The upgrade of the span of opening improves the likelihood to get nourishment. The steps followed for ALO algorithm is described as

1. The component of the framework which holds the places of preys is introduced arbitrarily with estimate ${ }^{\left[M_{\mathrm{Pr} e y}\right]_{N P \times D}}$.

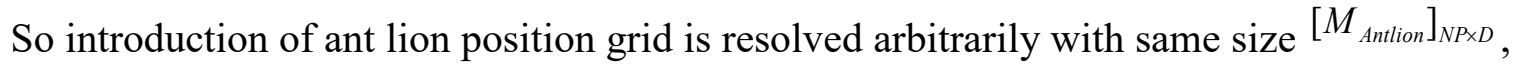
where NP and D are the population and measurement of plan factors, respectively. For this issue irregular in statement is in the middle of 0 to 2 .

Useful estimations of the ant lion and prey are dictated by

$$
\begin{gathered}
F_{\text {Prey }}=f\left(M_{\text {Prey }}\right) \\
F_{\text {Antlion }}=f\left(M_{\text {Antlion }}\right)
\end{gathered}
$$

Where $F_{\text {Prey }}$ is a variety of wellness estimations of arbitrarily introduced MPrey and FAntlion is the variety of wellness estimations of $M_{\text {Antlion. }}$

2. The antlion with the best fitness is allocated as the best.

3. Roulette wheel is utilized to choose antlions which give higher likelihood of fitting ant lions to chase preys. 
4. The base and greatest vector of $\mathrm{i}^{\text {th }}$ factors $c_{i}^{g}$ and $d_{i}^{g}$ individually are modified as in equation (10) and (11) respectively.

$$
\begin{aligned}
& c_{i}^{g}=A L_{i}^{g}+c^{g} \\
& d_{i}^{g}=A L_{i}^{g}+d^{g}
\end{aligned}
$$

Where $A L_{i}^{g}$ is the position of $\mathrm{i}^{\text {th }}$ antlion at $\mathrm{g}^{\mathrm{th}}$ generation. $\mathrm{c}^{\mathrm{g}}$ and $\mathrm{d}^{\mathrm{g}}$ might be described as

$$
c^{g}=\frac{c^{g}}{I}, d^{g}=\frac{d^{g}}{I}, \text { and } I=10^{w} \frac{g}{n}
$$

Where $\mathrm{w}$ is a round number chosen between 2 to 6 based on new generation.

5. The activities of preys are random in nature and may be shown in equation (12).

$$
X(g)=[0, \operatorname{cumsum}(2 \mathrm{r}(\mathrm{g} 1)-1), \operatorname{cumsum}(2 \mathrm{r}(\mathrm{g} 2)-1), \ldots, \operatorname{cumsum}(2 \mathrm{r}(\mathrm{gn})-1)
$$

Where cumulative sum is found by cumsum. $\mathrm{g}$ and $\mathrm{n}$ are the generation and peak generation number respectively. $\mathrm{r}$ is a random probability distribution function described in equation (13).

$$
r(g)=\left\{\begin{array}{lll}
1 & \text { if } & \text { rand }>0.5 \\
0 & \text { if } & \text { rand } \leq 0.5
\end{array}\right.
$$

6. The status of preys is modified by equation (14).

$$
P_{i}^{g}=\frac{R_{P}^{g}+R_{E}^{g}}{2}
$$

Where $R_{P}^{g}$ and $R_{E}^{g}$ are the strange changes around antlion and best respectively.

7. The functional values of preys are determined.

8. The antlion is updated by its analogous fitter prey as described in equation (15).

$$
A L_{i}^{g}=P_{i}^{g} \quad \text { if } f\left(P_{i}^{g}\right)>f\left(A L_{i}^{g}\right)
$$

9. The practical value of preys is determined as explain previously.

10. Elite value is updated by the antlion with fitness value better than elite.

11. Steps from 4 to 10 are repeated until maximum generation reached.

In the present work, the gains of PID controllers are tuned by ALO algorithm to enhance the power of the PV module.

\section{RESULTS AND DISCUSSION}

ALO algorithm is executed for 50 iterations with 50 populations to resolve the steps to discover the optimal gain parameters of PID controllers. The objective of the algorithm is to hunt the parameters within a specified limit as described in equation (16). 


$$
0.001 \leq K_{p}, K_{I} \text { and } K_{D} \leq 2
$$

The optimal values of $\mathrm{Kp}, \mathrm{K}_{\mathrm{I}}$, and $\mathrm{K}_{\mathrm{D}}$ are $0.0711,0.9079$ and 1.1260 , respectively. The performance of PV module by conceding power, voltage and current are portrayed in Figure 7, Figure 8 and Figure 9, respectively.

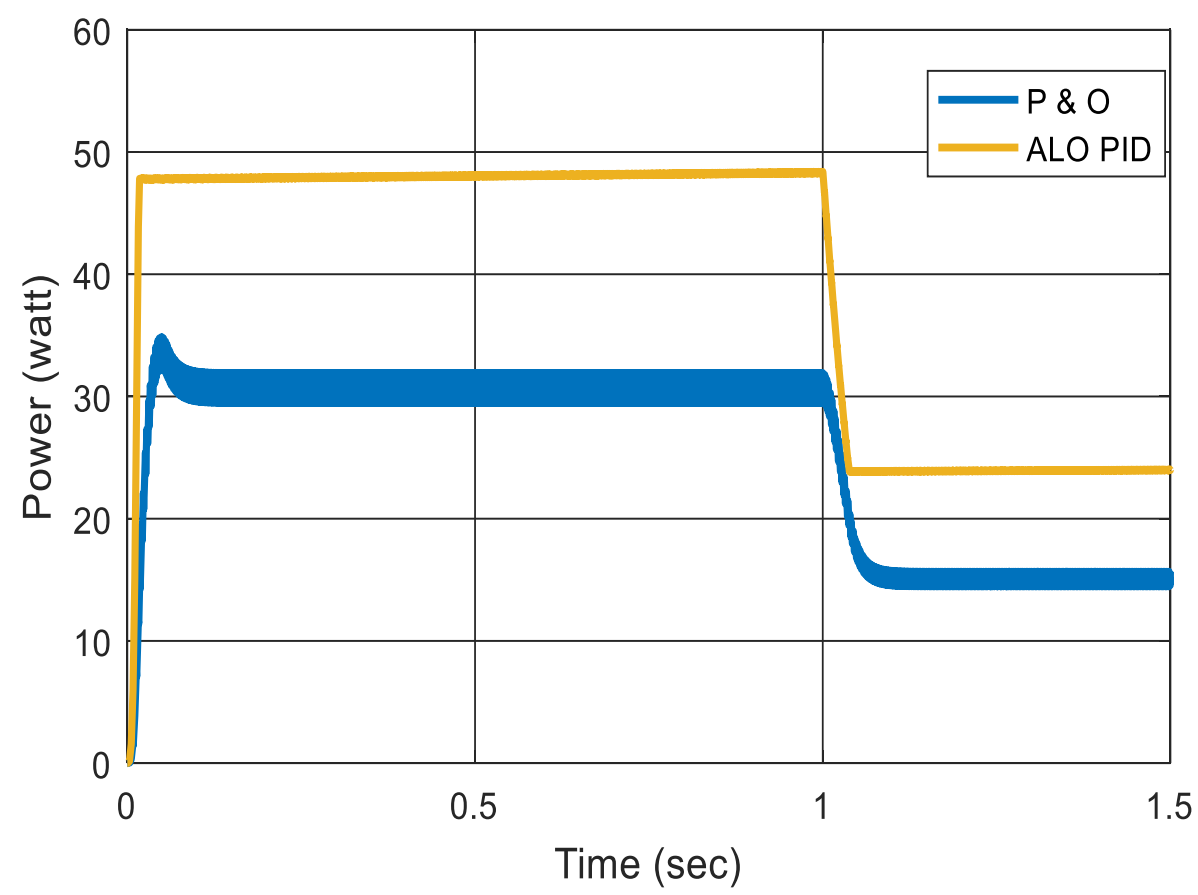

Figure 7. Power vs Time graph

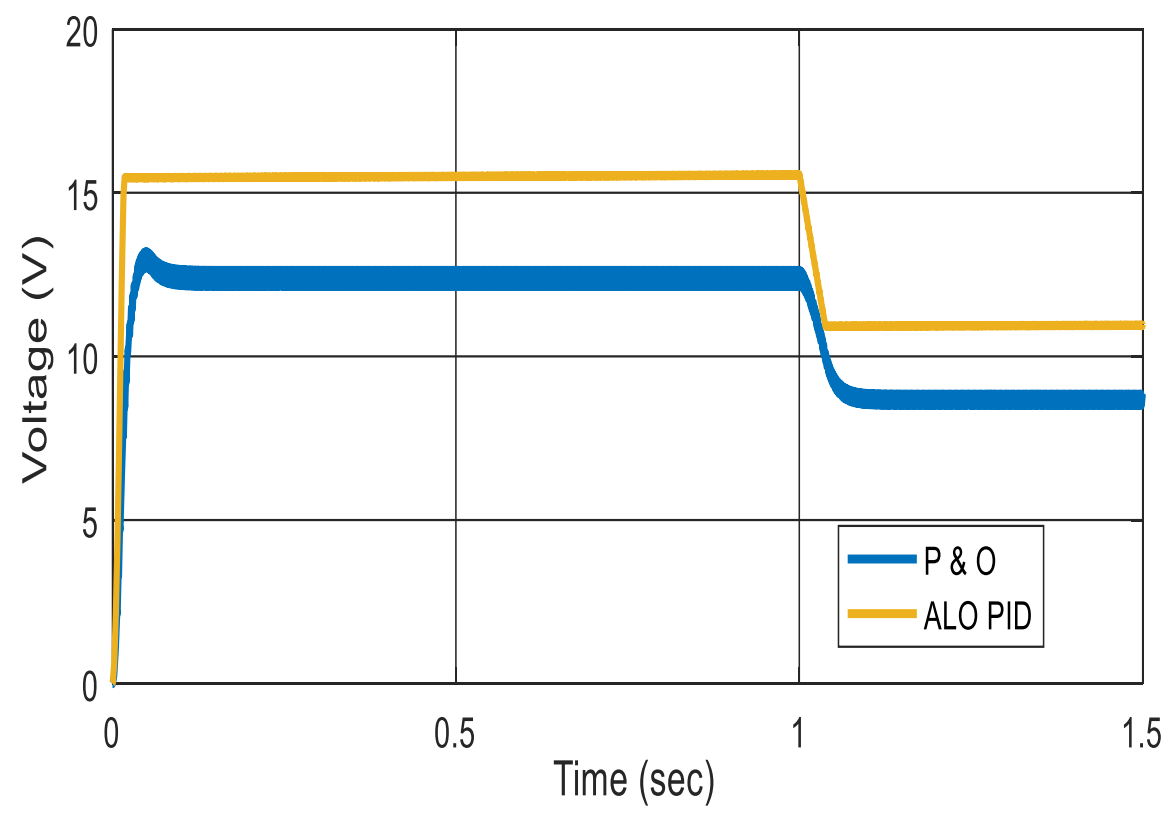

Figure 8. Voltage vs Time graph 


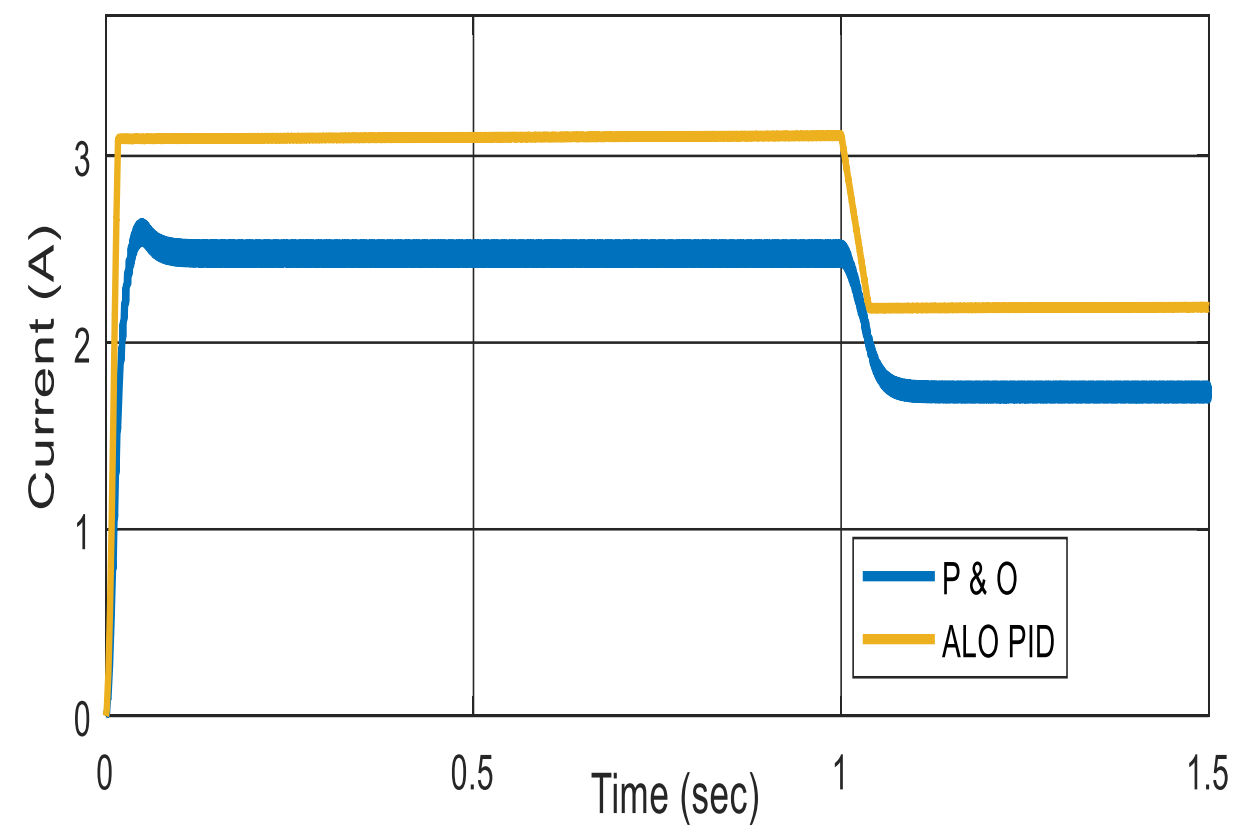

Figure 9. Current vs Time graph

The performance parameters of the output of PV module are tabulated in Table 2 to provide a fair supremacy of PID based MPPT controller over P \& O technique.

Table 2. Performance response of output

\begin{tabular}{ccccccc}
\hline $\begin{array}{c}\text { Performance } \\
\text { Parameters }\end{array}$ & \multicolumn{3}{c}{$\begin{array}{c}\text { P\&O } \\
\text { based MPPT }\end{array}$} & \multicolumn{3}{c}{$\begin{array}{c}\text { PID } \\
\text { based MPPT }\end{array}$} \\
\hline & $\mathrm{P}$ & $\mathrm{V}$ & $\mathrm{I}$ & $\mathrm{P}$ & $\mathrm{V}$ & $\mathrm{I}$ \\
\cline { 2 - 7 } Maximum & 30.55 & 12.385 & 2.477 & 48.02 & 15.465 & 3.094 \\
Overshoot & 2.94 & 0.56 & 0.12 & 0 & 0 & 0 \\
Settling time & 0.072 & 0.075 & 0.06 & 0.018 & 0.017 & 0.017 \\
Rise time & 0.032 & 0.0307 & 0.038 & 0.017 & 0.016 & 0.016 \\
Delay time & 0.019 & 0.012 & 0.013 & 0.012 & 0.011 & 0.010 \\
Oscillation & 2.432 & 0.492 & 0.098 & 0.061 & 0.012 & 0.002 \\
\hline
\end{tabular}
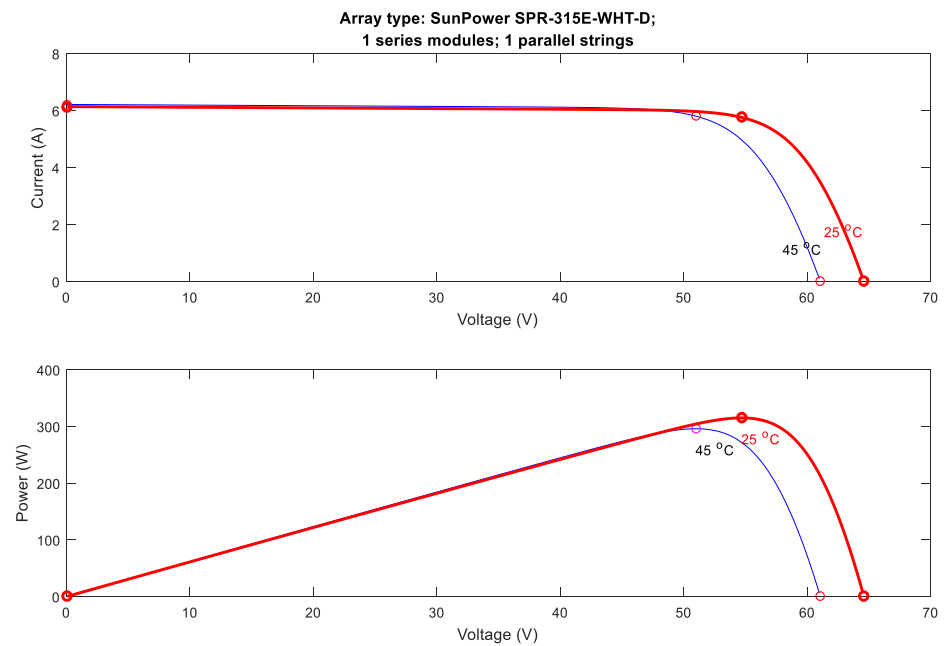

Figure 10. I-V and P-V characteristics of PV module 
The I-V and P-V characteristics are illustrated in Figure 10. The settling time, rise time, delay time and oscillation of output responses (power, voltage and current) of PV module with ALO optimized PID based MPPT controller are lower than the P \& O based MPPT technique. Overshoot evaluated by considering the difference between steady state maximum power and maximum power. Implementation of proposed MPPT technique enhances the responses of PV module remarkably. Finally, ALO optimized PID based MPPT technique is validated as a better technique over P \& O based MPPT technique to enhance the efficiency of the PV module.

\section{CONCLUSION}

The purpose of this paper is to design a solar system and to enhance the efficiency of the system by implementing PID based MPPT technique. The PID based MPPT controller optimized by ALO algorithm is validated as an improved controller over P \& O based MPPT controller of the solar system. Temperature, irradiance and load are the imperative factors which influence the current, voltage and power of the solar cell. This $\mathrm{PID}$ and $\mathrm{P} \& \mathrm{O}$ based MPPT controller is executed by diverging the irradiance (1000 $\mathrm{W} / \mathrm{m}^{2}$ to $\left.700 \mathrm{~W} / \mathrm{m}^{2}\right)$ and with constant temperature $\left(45^{\circ} \mathrm{C}\right)$ and load $(24 \Omega)$. The error signal is evaluated by the contrast of reference voltage and measured process voltage to achieve relevant gate pulse of the converter. The output voltage is enormously influenced by duty cycle of the gate pulse. The ALO optimized PID based MPPT techniques is validated over $\mathrm{P} \& \mathrm{O}$ technique to achieve maximum power, current and voltage with minimum oscillation, settling time, rise time and delay time.

\section{CONFLICTS OF INTEREST}

The authors declare that there is no conflict of interests regarding the publication of this paper.

\section{REFERENCES}

[1] T. Esram and P. L. Chapman, "Comparison of Photovoltaic Array Maximum Power Point Tracking Techniques," IEEE Trans. Energy Convers., vol. 22, no. 2, pp. 439449, 2007.

[2] A. Al-Diab and C. Sourkounis, "Variable step size P\&O MPPT algorithm for PV systems," Proc. Int. Conf. Optim. Electr. Electron. Equipment, OPTIM, pp. 10971102, 2010. DOI: 10.1109/OPTIM.2010.5510441

[3] K. Ishaque and Z. Salam, "A review of maximum power point tracking techniques of PV system for uniform insolation and partial shading condition," Renew. Sustain. Energy Rev., vol. 19, pp. 475-488, 2013.

[4] J. Ahmed and Z. Salam, "A Maximum Power Point Tracking (MPPT) for PV system using Cuckoo Search with partial shading capability," Appl. Energy, vol. 119, pp. $118-130,2014$. 
[5] M. Z. Ramli and Z. Salam, "A simple energy recovery scheme to harvest the energy from shaded photovoltaic modules during partial shading," IEEE Trans. Power Electron., vol. 29, no. 12, pp. 6458-6471, 2014.

[6] Y. R. Yang, "A Fuzzy Logic Controller for Maximum Power Point Tracking with 8Bit Microcontroller," In: Proc., IECON 2010 - 36th Annual Conference on IEEE Industrial Electronics Society, pp: 2895-2900, 2010. DOI: 10.1109/iecon.2010.5675084.

[7] Y.H. Liu, C.L. Liu, J.W. Huang, and J.H. Chen, "Neural-network-based maximum power point tracking methods for photovoltaic systems operating under fast changing environments," Sol. Energy, vol. 89, pp. 42-53, 2013.

[8] N. A. Kamarzaman and C. W. Tan, "A comprehensive review of maximum power point tracking algorithms for photovoltaic systems," Renew. Sustain. Energy Rev., vol. 37, pp. 585-598, 2014.

[9] A. Reza, M. Hassan, and S. Jamasb, "Classification and comparison of maximum power point tracking techniques for photovoltaic system: A review," Renew. Sustain. Energy Rev., vol. 19, pp. 433-443, 2013.

[10]N. Femia, G. Petrone, G. Spagnuolo, and M. Vitelli, "Optimization of Perturb and Observe Maximum Power Point Tracking Method," IEEE Transactions on Power Electronics, vol. 20, no. 4, pp. 963-973, 2005.

[11]S. Hoffmann and M. Koehl, "Investigation on the Impact of Macro- and MicroClimate on the Potential Induced Degradation," In: Proc., 2013 IEEE 39th Photovoltaic Specialists Conference (PVSC), pp: 1822-1825, 2013. DOI: 10.1109/pvsc.2013.6744496

[12]J. R. Nayak, B. Shaw, and B. K. Sahu, "Application of adaptive-SOS (ASOS) algorithm based interval type-2 fuzzy-PID controller with derivative filter for automatic generation control of an interconnected power system", Int. J. Engineering Science and Technology, 2018. DOI: 10.1016/j.jestch.2018.03.010.

[13]J.R. Nayak, B. Shaw, S. Das, and B.K. Sahu, Design of MI fuzzy PID controller optimized by Modified Group Hunting Search algorithm for interconnected power system, Microsyst. Technol., 2018. DOI: 10.1007/s00542-018-3788-3.

[14]H. Shareef, A. H. Mutlag, and A. Mohamed, "A novel approach for fuzzy logic PV inverter controller optimization using lightning search algorithm," Neuro computing, vol. 168, pp. 435-453, 2015.

[15]P.C. Cheng, B.R. Peng, Y.-H. Liu, Y.S. Cheng, and J.W. Huang, "Optimization of a Fuzzy-Logic-Control-Based MPPT Algorithm Using the Particle Swarm Optimization Technique," Energies, vol. 8, no. 6, pp. 5338-5360, 2015.

[16]A. S. Oshaba, E. S. Ali, and S. M. AbdElazim, "PI controller design for MPPT of photovoltaic system supplying SRM via BAT search algorithm," Neural Comput. Appl., vol. 28, no. 4, pp. 651-667, 2017.

[17]R. Nagarajan, R. Yuvaraj, V. Hemalatha, S. Logapriya, A. Mekala, and S. Priyanga, "Implementation of PV - Based Boost Converter Using PI Controller with PSO Algorithm,” Int. J. Eng. Comput. Sci., vol. 6, no. 3, pp. 20479-20484, 2017. DOI: 10.18535/ijecs/v6i3.14

[18]L. ZAGHBA, N. TERKI, A. BORNI, A. BOUCHAKOUR "Robust maximum power point tracking technique and PI current controller design for grid connected PV system using MATLAB/SIMULINK," Journal of Electrical Engineering, vol. 15, pp. 315-320, 2015. 
[19]A. Neçaibia, S. Ladaci, A. Charef, and J. J. Loiseau, "Fractional order extremum seeking approach for maximum power point tracking of photovoltaic panels," Front. Energy, vol. 9, no. 1, pp. 43-53, 2015.

[20]E. S. Ali, S. M. AbdElazim, and A. Y. Abdelaziz, "Ant Lion Optimization Algorithm for renewable Distributed Generations," Energy, vol. 116, pp. 445-458, 2016.

[21] S. Mirjalili, “The Ant Lion Optimizer,” Adv. Eng. Softw., vol. 83, pp. 80-98, 2015.

Article copyright: (C) 2018 Raj Kumar Sahu and Binod Shaw. This is an open access article distributed under the terms of the Creative Commons Attribution 4.0 International License, which permits unrestricted use and distribution provided the original author and source are credited.

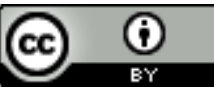

